\title{
Thyrotropin Receptor Blocking Antibodies
}

\section{(ㄷ) (i) $($ ) $\odot$}

Authors

Tanja Diana', Paul D. Olivo², George J. Kahaly

Affiliations

1 Molecular Thyroid Research Laboratory, Department of Medicine I, Johannes Gutenberg University (JGU) Medical Center, Mainz, Germany

2 Department of Molecular Microbiology, Washington University Medical School, St. Louis, Missouri, USA

\section{Key words}

TSH receptor blocking autoantibodies, cell-based bioassay, binding assay, Hashimoto's thyroiditis, Graves' disease

received $\quad 04.06 .2018$

accepted 22.08.2018

Bibliography

DOI https://doi.org/10.1055/a-0723-9023

Published online: 4.10.2018

Horm Metab Res 2018; 50: 853-862

(c) Georg Thieme Verlag KG Stuttgart · New York

ISSN 0018-5043

Correspondence

Prof. George J. Kahaly

JGU Medical Center

Langenbeckstraße 1

55131 Mainz

Germany

Tel.: +49-6131-17-2290, Fax: +49-6131-17-3460

george.kahaly@unimedizin-mainz.de

\section{ABSTRACT}

Autoantibodies $(\mathrm{Ab})$ against the thyroid-stimulating hormone receptor (TSHR) are frequently found in autoimmune thyroid disease (AITD). Autoantibodies to the TSHR (anti-TSHR-Ab) may mimic or block the action of TSH or be functionally neutral. Measurement of anti-TSHR-Ab can be done either via competitive-binding immunoassays or with functional cell-based bioassays. Antibody-binding assays do not assess anti-TSHR-Ab functionality, but rather measure the concentration of total anti-TSHR binding activity. In contrast, functional cell-based bioassays indicate whether anti-TSHR-Ab have stimulatory or blocking activity. Historically bioassays for anti-TSHR-Ab were research tools and were used to study the pathophysiology of Graves' disease and Hashimoto's thyroiditis. In the past, bioassays for anti-TSHR-Abs were laborious and time-consuming and varied widely in performance from laboratory to laboratory. Recent advances in the development of cell-based assays, including the application of molecular engineering, have led to significant improvements that have enabled bioassays to be employed routinely in clinical laboratories. The prevalence and functional significance of TSHR blocking autoantibodies (TBAb) in autoimmune hypothyroidism has been less well investigated compared to TSHR stimulating Ab. There is an increasing body of data, however, that demonstrate the clinical utility and relevance of TBAb, and thus the importance of TBAb bioassays, in the diagnosis and management of patients with AITD. In the present review, we summarize the different methods used to measure TBAb, and discuss their prevalence and clinical relevance.

\section{Abbreviations}

$\begin{array}{ll}\text { AA } & \text { Amino acids } \\ \text { ATD } & \text { Antithyroid drugs } \\ \text { Ab } & \text { Autoantibodies } \\ \text { anti-TSHR-Ab } & \text { Autoantibodies to the TSHR } \\ \text { AITD } & \text { Autoimmune thyroid disease } \\ \text { bTSH } & \text { Bovine TSH } \\ \text { CHO } & \text { Chinese hamster ovary } \\ \text { CREB } & \text { cAMP response element-binding protein } \\ \text { CAMP } & \text { Cyclic adenosine 3',5'-monophosphate } \\ \text { FRTL-5 } & \text { Fisher rat thyroid line-5 } \\ \text { FDA } & \text { Food and Drug Administration }\end{array}$

GD

HT

$\lg G$

L-T4

LH-CG

MAb

Mc4

RAI

RIA

TBII

TBAb

TSAb

TSH
Graves' disease

Hashimoto's thyroiditis

Immunoglobulin G

Levothyroxine

Luteinizing hormone-choriongonadotropin Monoclonal antibody

Mutant chimeric 4

Radioactive iodine

Radio-immunoassay

TSHR-binding inhibitory immunoglobulin TSHR-blocking autoantibodies

TSHR-stimulating autoantibodies

Thyroid-stimulating hormone 
T4

T3

TSHR

wt

\section{Introduction}

Autoimmune thyroid diseases (AITD) are characterized through increased familial clustering, reduced DNASE1 gene expression, CTLA-4 polymorphisms, and are strongly associated with the major histocompatibility (MHC) complex [1-4]. However, autoantibodies to various thyroid antigens are the most important biomarkers that are used to differentiate AITD from other thyroid conditions. Whereas antibodies to thyroid peroxidase (TPO) and thyroglobulin (Tg) neither play a major nor casual role in the pathophysiology of AITD, antibodies to the TSHR play a unique role in the development of autoimmune hyper- and hypothyroidism. Autoantibodies to the TSHR (anti-TSHR-Ab) are directly involved in the pathophysiology of Graves' disease (GD) and Hashimoto's thyroiditis (HT). GD is caused by TSHR-stimulating antibodies (TSAb), which act as agonists by stimulating thyroid growth and thyroid hormone synthesis in an unregulated manner [5-7]. In contrast, blocking anti-TSHR$\mathrm{Ab}$ (TBAb) acts as TSHR antagonists, which block the action of the thyroid-stimulating hormone (TSH) and can cause the hypothyroidism of HT. Anti-TSHR-Ab can be detected either with immunoassays, which measure TSHR-binding inhibitory immunoglobulins (TBII) [8] or with cell-based bioassays, which measure either TSAb or TBAb [9]. The advantages and disadvantages of binding assays versus functional bioassays for anti-TSHR-Ab, with special emphasis on TBAb, are shown in $>$ Table 1.

Bioassays involve the measurement of signal transduction pathways mediated by binding of a ligand to the TSHR $[10,11]$. Compared to TBII binding assays, cell-based bioassays are more sensitive in detecting low anti-TSHR-Ab concentrations and exclusively differentiate between the anti-TSHR-Ab functionality [12, 13]. Historically bioassays that measure TSAb were based on measurement of cAMP levels in cells using radio-immunoassays (RIA) [14-19]. More recently, non-radioactive methods to measure cAMP have been used. In addition, cell lines that contain a cAMP-inducible reporter gene such as luciferase have been employed to measure TSAb [20-23]. Bioassays that measure TSHR-blocking activity are based on the same cell-based systems, but they detect the ability of patient antisera to block TSH or TSAb-stimulated cAMP levels or luciferase expression [23-25].

Most reviews of anti-TSHR-Ab have focused primarily on TSAb. In the present, paper we will focus on TBAb. Compared to TSAb [2628], the measurement and clinical utility of functional TBAb have been less well investigated. Many reports have studied the occurrence of TBAb in various autoimmune diseases associated with hypothyroidism such as autoimmune-induced atrophic thyroiditis or primary myxedema [29-34]. The prevalence of TBAb in these various conditions is still controversial. Other investigations have focused on the role of TBAb in congenital and neonatal hypothyroidism associated with maternal AITD [31,35-38]. The importance of TBAb in congenital hypothyroidism, however, has been questioned. Ever since it has been known that anti-TSHR-Ab exhibit different functional activities it has been suspected that certain patients might contain both TSAb and TBAb, and that this may explain certain clinical presentations. Recent evidence has proven that a patient can have both TSAb and TBAb by isolating separate monoclonal antibodies (MAb) with stimulatory and blocking activity from the lymphocytes of the same patient $[39,40]$. In addition, there has been speculation that patients with GD may shift between stimulating and blocking antibodies as they transition from hyperthyroid to hypothyroid and vice versa. The mechanism of transition from TSAb to TBAb is most probably due to a different ratio between the two functional autoantibodies; while the exact antigenic sites of the TSHR against TBAb and TSAb are strongly overlapping and not completely defined. In the present paper, we will review the historical and currently used assays used for the measurement of TBAb activity and discuss their clinical applications.

- Table 1 Advantages and disadvantages of binding (TBII) Assays versus functional bioassay for TSHR blocking autoantibodies.

\begin{tabular}{|c|c|c|}
\hline & Advantages & Disadvantages \\
\hline \multirow[t]{4}{*}{ Binding Assays (TBII) } & International standardization with reference material & Do not discriminate the functional antibody type \\
\hline & Easy handling and performance & Only measure antibody binding to the TSHR \\
\hline & $\begin{array}{l}\text { M22 and KSAb1, human and mouse thyroid stimulating mAbs } \\
\text { respectively, have replaced bTSH in newer automated binding assays }\end{array}$ & TBII levels reflect total anti-TSHR-Ab \\
\hline & Commercially automated assays are available & \\
\hline \multirow[t]{5}{*}{ Functional Bioassay } & Measure the net sum of the functional activity & Absence of an international standard \\
\hline & $\begin{array}{l}\text { Discriminate the functional antibody type, specifically identifying } \\
\text { TBAb }\end{array}$ & More time consuming than TBII \\
\hline & Higher analytical sensitivity than binding assays (TBII) & Requires experienced laboratory technician \\
\hline & $\begin{array}{l}\text { Newly developed bioassays: minimal handling of the cells, no IgG } \\
\text { purification, no serum starvation, no serum concentration }\end{array}$ & Not widely available \\
\hline & $\begin{array}{l}\text { Predict fetal/neonatal risk for hypothyroidism in pregnant women with } \\
\text { active or treated AITD }\end{array}$ & Not automated yet \\
\hline
\end{tabular}




\section{Pathophysiology of Hashimoto's Thyroiditis}

Hashimoto's thyroiditis is the major cause of autoimmune hypothyroidism and GD is the primary cause of autoimmune hyperthyroidism. Whereas the hyperthyroidism of GD is exclusively due to TSAb, there are several mechanisms, by which hypothyroidism develops in HT. The primary pathological basis of decreased thyroid hormone production is related to immune-mediated apoptosis and cytolysis of thyrocytes. Normal thyroid epithelial cells express a variety of death receptors including Fas and activation of the Fas-ligand-Fas signaling system contributes to the follicular cell destruction characteristic of HT. In addition, cytokine stimulation from antigen-presenting cells and Th1 cells (IL-1) can induce functional Fas and also Fas ligand on thyroid follicular cells which can lead to self-apoptosis [41]. Furthermore, the accumulation of activated $T$ cells expressing Fas ligand may induce apoptosis of thyrocytes directly by interacting with Fas on the cells [42].

The characteristic histopathological abnormalities of HT are profuse lymphocytic infiltration, lymphoid germinal centers, and destruction of thyroid follicles. Intrathyroidal lymphocytes are both $\mathrm{T}$ and $B$ cells. Recent insight into the development of intrathyroidal germinal centers and lymph vessels suggests the importance of local production of chemokines [43]. B cells from thyroid tissue of patients with HT are activated, as indicated by their ability to secrete thyroid antibodies spontaneously in vitro. Thus, the thyroid gland may be a major site of thyroid Ab secretion. Anti-Tg and anti-TPO Ab of the appropriate $\mathrm{gG}$ subclass have the potential to fix complement, and thus antibody-mediated complement-dependent cytotoxicity (CDC) may contribute to thyroid damage in some patients with $\mathrm{HT}$ [44]. More important may be the role of thyroid Ab secreting $B$ cells in presenting thyroid antigen to the $T$ cells, which react with processed thyroid antigens and peptides derived from these antigens. These activated $T$ cells secrete cytokines, which themselves activate a variety of other immune cells. T cells have two roles in this disease: a role in Ab production (a Th2 type of function) and a role in the apoptotic destruction of thyroid cells by activating cytotoxic T cells (a Th1 function) [45]. The Th1 CD4 + lymphocytes, when stimulated by antigen, secrete interleukin-2 (IL-2), interferon gamma, and tumor necrosis factor-beta. In contrast, Th2 cells, when stimulated by antigens, secrete IL-4 and IL-5. Both types of T cells are found in thyroid tissue of patients with $\mathrm{HT}$, but Th1 cells predominate $[46,47]$. A T-cell clone that caused cytolysis of autologous thyroid cells has been reported in a patient with HT [48]. Finally, in addition to the various mechanisms of thyroid cell death, decreased thyroid hormone production in HT may be caused by TBAb which rather than causing thyroid cell death, bind to the TSHR and interfere with the ability of thyrocytes to respond to TSH. The relative contribution of all of these immunopathophysiological mechanisms in $\mathrm{HT}$ varies from patient to patient.

\section{Bioassays for TSHR-Blocking Autoantibodies}

\section{Definition of blocking activity}

Anti-TSHR-Ab that bind to the TSHR and neither activate the cyclic AMP pathway nor stimulate thyroid hormone synthesis, but rather act as TSHR antagonists inhibiting the activation of signal transduction pathways, are defined as blocking anti-TSHR-Ab or TBAb $[49,50]$.

\section{Historical methodology}

Early bioassays for the detection of TBAb were based on the same cell-based systems used for TSAb, including thyroid plasma membranes, thyroid tissue slices, and eventually cultured thyroid cells [51-53]. In contrast to TSAb bioassays, TBAb bioassays detected the ability of patient sera to block various concentration of bovine TSH (bTSH) or TSAb-stimulated cAMP levels. Alternative TBAb assay systems were sought to address the limitations associated with using thyroid tissue or primary thyroid cells. A major advance in the field was the isolation of a cell line from normal rat thyroid (Fisher rat thyroid cell line, FRTL-5), which endogenously expressed the TSHR and was TSH-dependent for growth [54]. Importantly, FRTL-5 cells retained the main features of normal thyroid functions, such as hormone response, iodide uptake and thyroglobulin synthesis and could be maintained over the relatively long culture period which used by several investigators $[33,49,54]$.

Further improvement in the detection of blocking activity was achieved with a luminescent bioassay for TBAb utilizing the $\mathrm{CHO}$ K1 cell line (named lulu * ) stably transfected with the human TSHR and a luciferase gene under control of a promoter with a cAMP responsive element [24]. Using CHO lulu cells and a luminescent assay for TBAb, twelve samples, previously shown to contain TBAb by an established method quantifying CAMP by RIA, were also positive by the luciferase-based assay [24]. The specificity of this assay was excellent in that 20/20 patients with systemic lupus erythematosus, $13 / 14$ with rheumatoid arthritis and $12 / 12$ with multinodular goiter were negative for TBAb. Bioassays using such engineered $\mathrm{CHO}$ cells have the advantage of expressing the human TSHR and they require less cumbersome procedures for cell culture [55].

Another $\mathrm{CHO}$ cell line was generated for the measurement of TBAb that stably expressed a TSHR/LH-CG receptor construct that was reported to have a reduced response to most TSAb [56]. This $M c 1+2$ TSHR has amino acid (AA) residues 8 to 165 from the extracellular region of the TSHR substituted by the residues 10 to 166 of the LH-CG receptor. The CHO Mc1 + 2 cell line was responsive to TSH as measured by CAMP induction [57]. In a follow up study the $\mathrm{CHO} \mathrm{Mc} 1+2$ cell line was compared with a wild type human TSHR $\mathrm{CHO}$ cell line, W25, for the measurement of TBAb [56]. A chimeric TSHR was also used in a coated tube assay for the detection of TBAb employing an adaptation of the TSH binding-inhibitory format [58]. This method utilized HEK-293 cells in which the wild-type TSHR of the TBII assay was exchanged for a chimeric receptor in which supposed TSAb epitopes (AA 8-165) were replaced by a TSH/Luteinizing hormone-choriongonadotropin (LH-CG) residues resulting in a chimeric receptor (chimera $A$ ) [57]. In studies using this assay sera from patients with GD and AITD were grouped according to their activity in a TBAb bioassy. At the decision threshold, the chimera assay had a sensitivity of $78 \%$ for TBAb with a specificity of $90.2 \%$, but correlation with the bioassay results was only moderate $(r=0.46)$. The technique was purported to allow the differentiation between sera containing only TBAb, both TBAb and TSAb, only TSAb, or sera without any bioactivity. Despite such efforts to map and remove stimulation-specific epitopes and incorporate chimer- 
ic receptors into assays for exclusive detection of TBAb, it is not clear that these efforts have been successful.

\section{Currently available TSHR-blocking antibody assays}

A bioassay is commercially available in Japan (Yamasa, Corp., Chosi, Chiba, Japan) that utilizes porcine thyroid gland cells for the measurement of TBAb with a CAMP RIA $[59,60]$. RSR Limited (Cardiff, UK) offers a research-use only service to measure TBAb. This assay uses $\mathrm{CHO}$ cells expressing the human TSHR and TBAb is detected by inhibition of porcine TSH-induced cAMP [61]. In another assay, autoantibodies inhibit the binding of M22 labeled with biotin to TSHR-coated enzyme-linked immunosorbent assay (ELISA) plate wells [62]. Recently, a bioassay for the TBAb measurement based on luciferase expression was described [23,25]. The assay uses the same Mc4 cell line, that is used in the FDA-cleared TSAb bioassay [22]. The chimeric construct in the Mc4 cells amino acid (AA) residues 262-368 of the human TSHR are substituted with the AA residues 262-334 from the rat LH-CG receptor [25]. There is no cell line available expressing a modified TSHR that binds exclusively to TSAb or TBAb including the Mc4 TSHR which was originally purported to have TBAb epitopes removed. The TBAb bioassay using $\mathrm{CHO}$ Mc4 cells was shown to provide excellent analytical performance and a high level of reproducibility [25]. A schematic of the TBAb bioassay principle is shown in $\mathbf{F i g}$. 1. Early in the development of this TBAb bioassay, CHO cells expressing either the chimeric human TSHR (Mc4) or the wild-type (wt) TSHR were compared side by side. Both $\mathrm{CHO}$ cell lines were induced with different con-

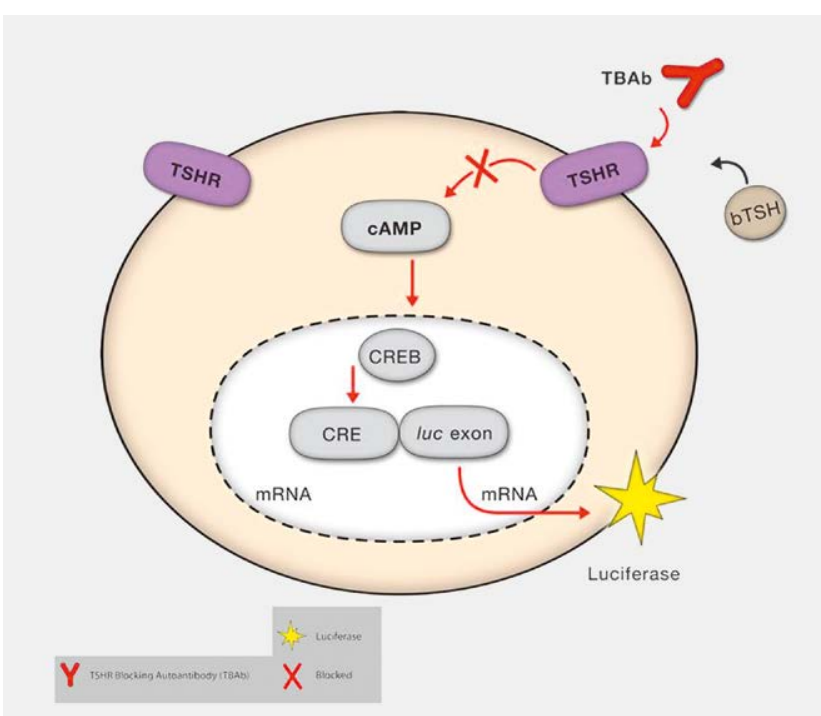

- Fig. 1 Schematic of reporter gene-based functional bioassay for TBAb. CHO cells are engineered to constitutively express the human TSHR and to express luciferase following induction of cAMP. The binding of bovine (b) TSH to the TSH receptor on the surface of the cells induces a signaling cascade that leads to an increase of intracellular cAMP and subsequently to the luciferase expression. However, the presence of blocking anti-TSHR-Ab (TBAb) in serum of patients with autoimmune thyroid diseases inhibits the bTSH stimulation of the luciferase reporter gene. The TBAb level is correlated with blocking activity which is defined as percent inhibition of luciferase expression relative to induction with bTSH alone. centrations of bTSH. The half maximal inhibitory concentration of $\mathrm{K}$ 1-70 MAb in CHO Mc4 cells was more than five-fold lower compared to the $\mathrm{CHO}$ wt cells. The $\mathrm{CHO}$ Mc4 cell line showed several advantages over the $\mathrm{CHO}$ wt cell line including a broader linear range in response to $\mathrm{bTSH}$, higher sensitivity in detecting blocking activity of the purely human blocking MAb K1-70 as well as detecting higher levels of blocking activity of TBAb positive sera from patients with AITD [23, 25].

Another TSAb/TBAb bioassay was reported that utilizes a unique cAMP detection method. $\mathrm{CHO}$ cells were engineered to express the TSHR and a calcium-activated bioluminescent protein [63]. Following TSHR activation, increased intracellular CAMP levels activate the cyclic nucleotide-gated calcium channel. The subsequent influx of calcium results in bioluminescence of aequorin which is quantified with a luminometer [63]. As with other TSAb bioassays, TBAb can be measured with minor modifications of the protocol [63].

- Table 2 summarizes first generation (CAMP RIA) and second generation (cAMP/luciferase) bioassays described for the measurement of TBAb. Although head-to-head comparisons are limited, the variable methodologies used to detect TBAb do not give identical results and thus it is difficult to compare studies on the prevalence of TBAb [24]. Finally, it is important to note that when sera contain both TSAb and TBAb, bioassays measure the net activity of stimulating and blocking antibodies and dilutional analysis of serum may be required to detect both activities [13,24]. At the time of publication there are no TBAb bioassays approved by U.S. or European regulatory agencies. Although second generation cAMP and luciferase assays using $\mathrm{CHO}$ cells have simplified the TBAb assay procedure, the availability of TBAb bioassays remains limited. Hopefully, this will change in the near future with increasing recognition of the importance of TBAb in evaluating and managing patients with AITD.

\section{Clinical Relevance and Clinical Applications of TBAb}

\section{Studies on TBAb in primary hypothyroidism}

One of the first studies that identified TBAb in patients with AITD reported on the inhibition of TSH-induced cAMP increase by IgG from patients with primary myxedema [29]. IgG fractions prepared from sera of patients with primary myxedema, goitrous HT, and controls, respectively, were tested for their ability to alter TSH stimulation of cAMP production in cultured human thyroid cells and the binding of TSH to its receptor. When compared with the CAMP increase induced by bTSH in the presence of normal IgG, cAMP accumulation was significantly inhibited by $\mathrm{lgG}$ from patients with primary myxedema. TSH-induced cAMP accumulation was not affected by IgG from patients with goitrous thyroiditis. These authors further studied TSH-stimulated CAMP response inhibitory immunoglobulins in patients with atrophic (primary myxedema) and goitrous HT and found TBAb in $40.5 \%$ and $17 \%$ patients with atrophic and goitrous thyroiditis, respectively [64]. In another study the prevalence of TBAb was also evaluated in hypothyroid patients with either goitrous or atrophic thyroiditis [30]. IgG was incubated with porcine thyroid cells in the presence of bTSH and the results were 
- Table 2 First generation (cAMP RIA assays)and second generation (cAMP/luciferase assays) for TSHR blocking autoantibodies.

\begin{tabular}{|c|c|c|c|c|c|}
\hline & Year & Species & $\begin{array}{l}\text { Assay } \\
\text { time }\end{array}$ & Comments & Reference \\
\hline \multirow{11}{*}{$\begin{array}{l}\text { FIRST generation assays } \\
\text { (cAMP radio-immunoassay) }\end{array}$} & 1978 & Human & 4 days & Human thyroid plasma membranes, adenyl cyclase activity & [51] \\
\hline & 1980 & Human & 4 days & $\begin{array}{l}\text { Human thyroid plasma membranes, IgG preparation by column } \\
\text { chromatography through DEAE-Sephadex }\end{array}$ & {$[52]$} \\
\hline & 1983 & Human & 4 days & $\begin{array}{l}\text { Thyroid adenoma cells, IgG fractions preparation by DEAE-Sephadex } \\
\text { column chromatography }\end{array}$ & [29] \\
\hline & 1985 & Human & 4 days & $\begin{array}{l}\text { Human thyroid plasma membranes, IgG preparation by DEAE-cellulose } \\
\text { column chromatography }\end{array}$ & [53] \\
\hline & 1987 & Rat & 4 days & FRTL-5 cells, IgG preparation by DEAE Sephadex & [33] \\
\hline & 1989 & Rat & $1-2$ weeks & FRTL-5 cells, IgG preparation by polyethylene glycol (PEG) precipitation & [68] \\
\hline & 1989 & Rat & $1-2$ weeks & $\begin{array}{l}\text { FRTL- } 5 \text { cells, IgG extraction by affinity chromatography on columns of } \\
\text { protein A-Sepharose }\end{array}$ & [66] \\
\hline & 1990 & Rat & $1-2$ weeks & FRTL-5 cells, IgG dialyzed in hypotonic buffer & [49] \\
\hline & 1999 & Porcine & 2 days & Porcine thyroid cells, IgG preparation by PEG precipitation & [59] \\
\hline & 1999 & Hamster & 2 days & CHO cells (clones JP02 and JP26) & [73] \\
\hline & 2000 & Hamster & 3 days & CHO cells (clone JP26) & [55] \\
\hline \multirow[t]{5}{*}{$\begin{array}{l}\text { SECOND generation assays } \\
\text { (cAMP / luciferase) }\end{array}$} & 1994 & Hamster & 4 days & $\begin{array}{l}\text { CHO JP09 cells transfected with the recombinant human TSHR, IgG } \\
\text { dialyzed and diluted in hypotonic buffer }\end{array}$ & {$[17]$} \\
\hline & 2001 & Hamster & 1 day & CHO cells (clone JP09) stably transfected with the TSHR (clone lulu *) & {$[24]$} \\
\hline & $\begin{array}{l}2004, \\
2009\end{array}$ & Hamster & $20-24 \mathrm{~h}$ & $\begin{array}{l}\text { CHO cells expressing the wild-type human TSHR, use of serum, } \\
\text { spectrophotometric cAMP immunoassay }\end{array}$ & {$[62,83]$} \\
\hline & 2013 & Hamster & $20 \mathrm{~h}$ & $\begin{array}{l}\text { Fresh frozen vials of CHO cells expressing the chimeric human TSHR } \\
\text { Mc4 and a luciferase reporter gene, use of serum, luminescence } \\
\text { (cAMP-dependent luciferase expression) }\end{array}$ & {$[23,25,76]$} \\
\hline & 2015 & Hamster & $8 \mathrm{~h}$ & $\begin{array}{l}\text { CHO cells expressing the wild-type human TSHR, use of serum, no } \\
\text { sterile conditions necessary, luminescence (cyclic nucleotide-gated } \\
\text { calcium channel and aequorin) }\end{array}$ & [63] \\
\hline
\end{tabular}

expressed as the percent inhibition of TSH-stimulated production of cAMP, as compared with production in a pool of $\mathrm{IgG}$ from normal subjects [30]. TBAb were detected in $9 \%$ and $25 \%$ of the patients with goitrous and atrophic thyroiditis, respectively [30]. In a case report TBAb were detected in a pre-pubertal severely hypothyroid boy (baseline serum TSH $254 \mathrm{mU} / \mathrm{l}$ ) with atrophic HT and decreased growth velocity [65].

Potent blocking type anti-TSHR-Ab was observed in the majority of patients with primary myxedema using a FRTL-5 cell-based bioassay in which the prevalence of TBAb in primary myxedema was $75 \%$ versus $0 \%$ in goitrous $\mathrm{HT}[66,67]$. In line with this, inhibition of TSH-stimulated RAI uptake in FRTL- 5 cells by crude lg fractions was reported for patients with goitrous and atrophic $H T$ as well as from patients with overt hypothyroidism $[16,68]$. TSH-stimulated RAI uptake was inhibited by the I $g$ fractions from TBII-positive patients with atrophic thyroiditis due to their TBAb positivity. The mean inhibition of TSH-stimulated RAI correlated with the ability of the Ig fractions to inhibit TSAb-stimulated RAI uptake $(r=0.882)$ and TSH-stimulated cAMP accumulation $(r=0.929)$ [16]. TBAb were also present in 6/41 (14.6\%) patients with hypothyroidism [68].

Other groups also evaluated Ab blocking the TSH-dependent cAMP production in FRTL-5 cells [33]. TBAb were evaluated in patients with primary autoimmune hypothyroidism and were detect- able in 15/23 patients with untreated idiopathic myxedema, and in 2/15 patients under L-T4 treatment. IgG from normal subjects or from 10 patients with non-autoimmune hypothyroidism did not cause any significant effect on the TSH-stimulated CAMP production. No correlation was found between TBAb and the thyroid microsomal Ab. These authors further studied the incidence of $A b$ blocking the TSH effect in vitro in patients with euthyroid or hypothyroid HT [49]. TBAb were detected in 12/26 (46\%), 1/27 (3\%), $3 / 32$ (9.4\%), and in 20/55 (36\%) patients with atrophic thyroiditis, euthyroid HT, HT + subclinical hypothyroidism, and in hypothyroid $H T$, respectively. The prevalence of TBAb was higher in atrophic thyroiditis vs. all other collectives. Mean TBAb levels in atrophic thyroiditis were higher than those in hypothyroid $\mathrm{HT}$ and subclinical HT. An inverse correlation was found between TBAb levels and estimated goiter weight.

The detection of Ab blocking TSH effects using CHO cells transfected with the cloned human TSHR was reported [17]. All IgGs producing an inhibition greater than two standard deviations from the mean of controls ( $>25 \%$ ) were considered positive for TBAb. TBAb were detected in 1/8 (12.5\%), 7/30 (23.3\%), and 16/47 (34\%) patients with subclinical hypothyroid HT, hypothyroid HT and atrophic thyroiditis, respectively. This group used the same bioassay to demonstrate that humoral thyroid autoimmunity was not 
involved in the pathogenesis of myxedematous endemic cretinism [69]. Further and unlike TSAb, which are restricted to the IgG1 subclass suggesting an oligoclonal origin, the $\mathrm{lgG}$ subclass distribution of TBAb in primary hypothyroidism are not restricted to a single subclass and are therefore likely to have a polyclonal origin [70].

\section{Transient TBAb}

The often transient nature of TBAb was noted in a report that described the disappearance of TBAb and the spontaneous recovery from hypothyroidism in a patient with autoimmune thyroiditis [32]. In another study, 21 TBAb-positive patients were followed for $6-11$ years. TBAb disappeared in 15 patients (group 1), and persisted in six patients (group 2) [32]. Six patients in group 1 remained euthyroid, and nine became hypothyroid again within three months [32]. In contrast, all six patients with persistent TBAb positivity remained hypothyroid [32]. These authors, using a bioassay measuring porcine thyroid cell cAMP production, reported on their long-term follow-up ( $>10$ years) of TBAb-positive patients with hypothyroidism associated with atrophic and goitrous thyroiditis [30]. TBAb disappeared in 15/34TBAb-positive patients with hypothyroidism. The disappearance of TBAb correlated with recovery from hypothyroidism in 13 (87\%). All 10 TBAb-positive goitrous patients recovered from hypothyroidism while 19/24 (79\%) TBAb-positive patients with atrophic thyroiditis continued to be hypothyroid. Two of the 34 TBAb-positive patients with hypothyroidism developed TSAb-positive Graves' hyperthyroidism. In another study changes in stimulating and blocking Ab were evaluated in a patient undergoing three cycles of transition from hypo- to hyperthyroidism and back to hypothyroidism [71]. Throughout the entire course of variation in thyroid function, TSAb were consistently present, but TBAb appeared and disappeared. Monitoring such activity indicated that the emergence of TBAb heralded the onset of hypothyroidism. A change in activity from TSAb to TBAb was also observed in GD patients during pregnancy and may have contributed to the remission of GD during pregnancy [72]. Median TSAb levels decreased during pregnancy while TBAb increased. The increase of TBAb was observed among those who were in clinical remission before pregnancy. A negative correlation was observed between TBAb activity and free T4 levels during pregnancy.

\section{TBAb in GD}

A number of investigators have evaluated the prevalence of TBAb in GD. One study used $\mathrm{CHO}$ cell lines expressing different TSHR numbers (JP09 and JP26) and found that TBAb were frequently detected in GD [73]. Thirty-four (40\%) of 86 TSAb-negative GD patients were positive for TBAb. Differences between anti-TSHR-Ab bioactivity and inhibition of radioactive iodine (RAI)-labeled bTSH binding were noted in that only $78 \%$ of TBAb-positive sera detected with JP26 cells exhibited inhibition of RAI labeled bTSH binding [74]. Using JP09 CHO cells and unfractionated human serum, TBAb were detected in 4/24 (17\%) TSAb-negative, TBII-positive hypothyroid GD patients [19]. Blocking type anti-TSHR-Ab were detected by a radio-receptor bioassay in nine of $30 \mathrm{GD}$ sera (30\%) using unsolubilized porcine TSHR and FRTL-5 cells [75]. In 1079 unselected, consecutive patients with AITD and 302 healthy controls, TBAb was found in $4.2 \%$ of patients with GD [76]. Twenty-eight hyperthyroid GD patients on methimazole were followed for 13 years [77]. Eight of 28 (29\%) developed TBAb. Patients with TBAb responded well initially to ATD and showed earlier normalization of the serum T4 level compared to patients without TBAb.

\section{Transplacental transfer of TBAb}

In the first report on TBAb in neonatal hypothyroidism, IgGs inhibiting the CAMP response to TSH in human thyroid membranes were demonstrated in three infants with transient neonatal hypothyroidism suggesting that transplacental transfer of TBAb caused the hypothyroidism in these infants [78]. Further, transient neonatal hypothyroidism was found in a daughter of a mother who was receiving treatment for primary hypothyroidism due to HT. IgG from maternal serum blocked TSH-stimulated CAMP response, and CAMP-stimulated iodine uptake and organification in cultured thyroid cells [31]. Maternal TBAb were detected in mothers of babies with either congenital [37] or neonatal [79] hypothyroidism. The levels of TBAb, based on the ability of patient serum to inhibit TSH stimulated $3 \mathrm{H}$-cAMP production following incubation of FRTL-5 or $\mathrm{CHO}$-JPO9 cells with $3 \mathrm{H}$-adenine, decreased to control levels in the child with neonatal hypothyroidism within two months of birth but remained elevated in the mother's serum. Also, an infant with severe neonatal hypothyroidism due to transplacental passage of TBAb was described [36]. TBAb were detected using a cell line, which stably expresses the human TSHR and a CAMP-responsive luciferase reporter by their ability to inhibit TSH-stimulated luciferase expression. High levels of TBAb were detected in maternal serum and initially in the infant's serum, but TBAb decreased in the infant to within the reference range by $3-4$ months of age, illustrating the transient nature of this condition. Surprisingly, the thyroid function of this child did not return to normal on withdrawal of L-T4 therapy at 16 months of age when he developed transient compensated hypothyroidism.

\section{Isolation and in vivo Effects of Human Blocking Monoclonal Antibodies}

Human MAb against the TSHR were isolated from EBV-immortalized B-cells of patients with AITD both to understand the mechanism of the TSHR activation by Ab in patient serum and for the possible development of new treatments [40]. The serum of patients with AITD contains a mixture of polyclonal Ab whereas it was hypothesized that MAb, by virtue of their binding to a single epitope on the TSHR, could exhibit either pure stimulating or pure blocking activity in bioassays. This turned out to be the case and there have been several purely stimulatory and purely blocking MAb reported. Interestingly, a blocking MAb and a separate stimulating MAb were isolated from the same patient with GD [40].

Two human TSHR blocking MAb $129 \mathrm{H} 8$ and $122 \mathrm{G} 3$ were isolated from patients with GD that did not exhibit stimulatory activity in assays of thyroid function, but rather showed blocking activity in a bioassay [80]. A TSHR blocking MAb, 5C9 was also generated from the peripheral blood mononuclear cells of a female patient with post-partum thyroiditis and high serum TBIl levels (260 U/I). This patient's serum inhibited the stimulating activity of TSH, a stimulating human MAb (M22), mouse TSHR stimulating MAb and TSAb from human serum. $5 \mathrm{C} 9 \mathrm{lg} G$ bound with high affinity $\left(4 \times 10^{10}\right.$ $\mathrm{I} / \mathrm{mol}$ ) to the TSHR and inhibited the binding of TSH and M22 to the 
receptor. Similar to the patient's serum, $5 \mathrm{C} 9 \mathrm{IgG}$ preparations inhibited the cAMP stimulating activities of TSH, M22, serum TSAb, and TSHR-stimulating mouse MAb [81].

The human TSHR blocking MAb K1-70 was isolated in 2010 [40]. $B$ cells were obtained from the peripheral blood of a 54-year old woman with hypothyroidism and elevated TBII (160 U/I). The patient had an eight year history of AITD and she initially presented with hyperthyroidism, which was treated with methimazole. She then developed hypothyroidism and received levothyroxine. Evaluation of her serum showed both TSAb and TBAb with stimulating activity seen up to a dilution of $1 / 100$ and blocking activity of $82 \%$ inhibition at 1/10 dilution. Lymphocytes were infected with EBV and fused with a mouse/human hybrid cell line (K6H6/B5). Using a TBII assay supernatants of twelve thousand hybridoma clones were screened to identify the K1-70 clone which stably expresses around $40 \mathrm{mg} / \mathrm{l} \mathrm{of} \mathrm{gG}$. $\mathrm{K} 1-70 \mathrm{lgG}$ was purified from culture supernatants using protein $\mathrm{A}$ affinity chromatography. K1-70 inhibited cAMP induction by TSH, a stimulating MAb, and TSAb-positive sera in TSHR-expressing $\mathrm{CHO}$ cells [40]. K1-70 IgG1 lambda showed high binding affinity $\left(4 \times 10^{10}\right.$ $\mathrm{I} / \mathrm{mol}$ ) to the TSHR and bound to leucine-rich repeats 1-10 [82]. Furthermore, $\mathrm{K} 1-70$ was able to inhibit the stimulating activity of M22 in $\mathrm{CHO}$ cells expressing the human TSHR [82].

Human MAb produced against the TSHR were utilized to study their effects in vivo in laboratory animals [83, 84]. K1-70 was a potent inhibitor in vivo and was able to block the stimulating activity of M22. Furthermore K1-70 inhibited thyroid hormone secretion in rats following the intramuscular injection of $10-200 \mu \mathrm{g}$ per animal [84]. In rats treated with K1-70 alone, the total T4 and free T4 decreased in a dose-dependent manner. These results demonstrate that the activity of these MAb observed in bioassays correlates with their in vivo activities. Further, it provides strong evidence that the bioassays in which the activity of these anti-TSHR MAb were measured, though contrived for convenient measurement, are nevertheless physiologically relevant.

\section{Clinical Indications for TBAb and Concluding Remarks}

Our laboratory uses a TBAb bioassay based on the $\mathrm{CHO} / \mathrm{Mc} 4$ luciferase cells used in an FDA-cleared TSAb assay. When evaluating serum samples of approximately 2000 unselected, consecutive patients with AITD, seen and followed at our institution, TBAb were prevalent in both subjects with $\mathrm{HT}(11 \%)$ as well as in those with GD (8\%). The results of the TBAb measurement in the first 1400 patients have been reported $[25,76]$. It is becoming clear that in addition to the well-known T-cell-mediated cytotoxicity and the involvement of $\mathrm{CDC}$ in $\mathrm{HT}$, thyroid dysfunction and hypothyroidism can be induced by the occurrence and presence of TBAb. We and others have noted the occurrence of TBAb in patients with GD post radioactive iodine therapy and/or during treatment with antithyroid drugs [85], in patients with HT of recent onset, in AITD during pregnancy, as well as patients with non-thyroidal autoimmune disorders, that is, type 1 diabetes [38, 86-89]. The occurrence of TBAb during or after antithyroid drug treatment can impact the course of GD with TBAb-positive patients going into early remission or becoming spontaneously hypothyroid [85, 88]. Also, the majority of TBAb-positive subjects with
- Table 3 Potential indications for the measurement of thyrotropin receptor blocking antibodies.

1. Graves ' disease: post radioactive iodine treatment and/or during therapy with antithyroid drugs

2. Autoimmune Hashimoto's thyroiditis

3. Autoimmune thyroid disease in pregnancy

4. Neonatal hypothyroidism

5. Postpartum thyroid disease

6. Differential diagnosis of thyroiditis

7. Differential diagnosis of hypothyroidism

8. Down Syndrome *

9. Non-thyroidal autoimmune diseases (SLE, RA, type 1 diabetes, myasthenia)

* According to reference [92]; SLE: Systemic lupus erythematodus, RA: Rheumatoid arthritis.

TSH abnormally high (or high normal) / TPO-Ab positive
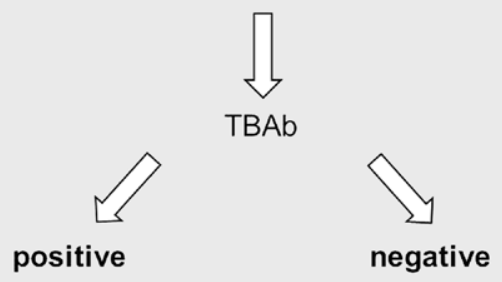

Autoimmune TBAb-

Induced Hypothyroidism

(overt or subclinical)

- Fig. 2 Diagnostic flowchart for TSHR blocking antibody-induced hypothyroidism.

HT were hypothyroid in contrast to TBAb-negative subjects who were predominantly euthyroid [76]. Regarding pregnancy and AITD, there is a real risk for the fetus in pregnant women with TSHR autoantibodies since both stimulating and blocking anti-TSHR-Ab can cross the placenta. Further, the risk for fetal/infant hyper- and hypothyroidism correlates with TSAb/TBAb levels [90, 91]. Therefore, and as listed in - Table 3, there are several potential clinical indications for the measurement of TBAb in patients with AITD. Further, and as illustrated in -Fig. 2 , in patients with abnormally elevated basal serum TSH and suspected AITD, the measurement of TBAb can help diagnose humoral immunity-induced hypothyroidism in which thyroid dysfunction is caused by TBAb. However, and as previously acknowledged in the introduction, when compared to the abundant literature pertaining to the clinical applications of TSAb, more prospectively designed, controlled studies are warranted to gain more insight and daily experience regarding both the clinical utility of measuring TBAb as well as their potential implications for diagnosis, differential diagnosis, management and follow-up of patients with AITD.

\section{Conflict of Interest}

TD has nothing to disclose. PDO and GJK consult for Quidel, USA. 
[1] Dittmar M, Libich C, Brenzel T, Kahaly G]. Increased familial clustering of autoimmune thyroid diseases. Horm Metab Res 2011; 43: 200-204

[2] Dittmar M, Woletz K, Kahaly G]. Reduced DNASE1 gene expression in thyroid autoimmunity. Horm Metab Res 2013; 45: 257-260

[3] Dultz G, Matheis N, Dittmar M, Bender K, Kahaly G]. CTLA-4 CT60 polymorphism in thyroid and polyglandular autoimmunity. Horm Metab Res 2009; 41: 426-429

[4] Barkia Beradhi S, Flesch BK, Hansen MP, Matheis N, Kahaly G]. HLA Class II Differentiates Between Thyroid and Polyglandular Autoimmunity. Horm Metab Res 2016; 48: 232-237

[5] Brent GA. Clinical practice. Graves' disease. N Engl J Med 2008; 358 : 2594-2605

[6] Weetman AP. Graves' disease. N Engl J Med 2000; 343: 1236-1248

[7] Kahaly G], Olivo PD. Graves' Disease. N Engl J Med 2017; 376: 184

[8] Zophel K, Roggenbuck D, Schott M. Clinical review about TRAb assay's history. Autoimmun Rev 2010; 9: 695-700

[9] Kahaly G], Diana T. TSH receptor antibody functionality and nomenclature. Front Endocrinol (Lausanne) 2017; 8: 28

[10] Lytton SD, Kahaly G]. Bioassays for TSH-receptor autoantibodies: an update. Autoimmun Rev 2010; 10: 116-122

[11] Diana T, Kahaly G]. Thyroid stimulating hormone receptor antibodies in thyroid eye disease - Methodology and clinical applications. Ophthal Plast Reconstr Surg 2018; 34 (4S Suppl): S13-S19

[12] Diana T, Wuster C, Kanitz M, Kahaly G]. Highly variable sensitivity of five binding and two bio-assays for TSH-receptor antibodies. J Endocrinol Invest 2016; 39: 1159-1165

[13] Diana T, Wuster C, Olivo PD, Unterrainer A, Konig J, Kanitz M, Bossowski A, Decallonne B, Kahaly GJ. Performance and specificity of 6 immunoassays for tsh receptor antibodies: A multicenter study. Eur Thyroid J 2017; 6: 243-249

[14] Vitti P, Valente WA, Ambesi-Impiombato FS, Fenzi GF, Pinchera A, Kohn LD. Graves' IgG stimulation of continuously cultured rat thyroid cells: A sensitive and potentially useful clinical assay. J Endocrinol Invest 1982; 5: 179-182

[15] Kasagi K, Konishi J, lida Y, Tokuda Y, Arai K, Endo K, Torizuka K. A sensitive and practical assay for thyroid-stimulating antibodies using FRTL-5 thyroid cells. Acta Endocrinol (Copenh) 1987; 115: 30-36

[16] Tokuda Y, Kasagi K, lida Y, Hatabu H, Misaki T, Arai K, Endo K, Konishi ]. Inhibition of thyrotropin-stimulated iodide uptake in FRTL-5 thyroid cells by crude immunoglobulin fractions from patients with goitrous and atrophic autoimmune thyroiditis. J Clin Endocrinol Metab 1988; 67: $251-258$

[17] Chiovato L, Vitti P, Bendinelli G, Santini F, Fiore E, Capaccioli A, Tonacchera M, Mammoli C, Ludgate M, Pinchera A. Detection of antibodies blocking thyrotropin effect using Chinese hamster ovary cells transfected with the cloned human TSH receptor. J Endocrinol Invest 1994; 17: 809-816

[18] Botero D, Brown RS. Bioassay of thyrotropin receptor antibodies with Chinese hamster ovary cells transfected with recombinant human thyrotropin receptor: clinical utility in children and adolescents with Graves disease. J Pediatr 1998; 132: 612-618

[19] Morgenthaler NG, Pampel I, Aust G, Seissler J, Scherbaum WA. Application of a bioassay with $\mathrm{CHO}$ cells for the routine detection of stimulating and blocking autoantibodies to the TSH-receptor. Horm Metab Res 1998; 30: 162-168

[20] Watson PF, Ajjan RA, Phipps ], Metcalfe R, Weetman AP. A new chemiluminescent assay for the rapid detection of thyroid stimulating antibodies in Graves' disease. Clin Endocrinol (Oxf) 1998; 49: 577-581
[21] Evans C, Morgenthaler NG, Lee S, Llewellyn DH, Clifton-Bligh R, John R, Lazarus JH, Chatterjee VK, Ludgate M. Development of a luminescent bioassay for thyroid stimulating antibodies. J Clin Endocrinol Metab 1999; 84: 374-377

[22] Lytton SD, Li Y, Olivo PD, Kohn LD, Kahaly G]. Novel chimeric thyroid-stimulating hormone-receptor bioassay for thyroid-stimulating immunoglobulins. Clin Exp Immunol 2010; 162: 438-446

[23] Li Y, Kim J, Diana T, Klasen R, Olivo PD, Kahaly G]. A novel bioassay for anti-thyrotrophin receptor autoantibodies detects both thyroid-blocking and stimulating activity. Clin Exp Immunol 2013; 173: 390-397

[24] Jordan NJ, Rinderle C, Ashfield J, Morgenthaler NG, Lazarus ], Ludgate M, Evans C. A luminescent bioassay for thyroid blocking antibodies. Clin Endocrinol (Oxf) 2001; 54: 355-364

[25] Diana T, Li Y, Olivo PD, Lackner K], Kim H, Kanitz M, Kahaly G]. Analytical performance and validation of a bioassay for thyroid-blocking antibodies. Thyroid 2016; 26: 734-740

[26] Diana T, Brown RS, Bossowski A, Segni M, Niedziela M, Konig J, Bossowska A, Ziora K, Hale A, Smith J, Pitz S, Kanitz M, Kahaly G]. Clinical relevance of thyroid-stimulating autoantibodies in pediatric graves' disease-a multicenter study. J Clin Endocrinol Metab 2014; 99: 1648-1655

[27] Ponto KA, Kanitz M, Olivo PD, Pitz S, Pfeiffer N, Kahaly G]. Clinical relevance of thyroid-stimulating immunoglobulins in graves' ophthalmopathy. Ophthalmology 2011; 118: 2279-2285

[28] Ponto KA, Diana T, Binder H, Matheis N, Pitz S, Pfeiffer N, Kahaly G]. Thyroid-stimulating immunoglobulins indicate the onset of dysthyroid optic neuropathy. J Endocrinol Invest 2015; 38: 769-777

[29] Konishi ], lida Y, Endo K, Misaki T, Nohara Y, Matsuura N, Mori T, Torizuka K. Inhibition of thyrotropin-induced adenosine 3'5'-monophosphate increase by immunoglobulins from patients with primary myxedema. J Clin Endocrinol Metab 1983; 57: 544-549

[30] Takasu N, Matsushita M. Changes of TSH-Stimulation Blocking Antibody (TSBAb) and Thyroid Stimulating Antibody (TSAb) Over 10 Years in 34 TSBAb-Positive Patients with Hypothyroidism and in 98 TSAb-Positive Graves' Patients with Hyperthyroidism: Reevaluation of TSBAb and TSAb in TSH-Receptor-Antibody (TRAb)-Positive Patients. J Thyroid Res 2012; 2012: 182176

[31] Takasu N, Mori T, Koizumi Y, Takeuchi S, Yamada T. Transient neonatal hypothyroidism due to maternal immunoglobulins that inhibit thyrotropin-binding and post-receptor processes. J Clin Endocrinol Metab 1984; 59: 142-146

[32] Takasu N, Yamada T, Takasu M, Komiya I, Nagasawa Y, Asawa T, Shinoda T, Aizawa T, Koizumi Y. Disappearance of thyrotropin-blocking antibodies and spontaneous recovery from hypothyroidism in autoimmune thyroiditis. N Engl J Med 1992; 326: 513-518

[33] Chiovato L, Vitti P, Lombardi A, Lopez G, Santini F, Macchia E, Fenzi GF, Mammoli C, Battiato S, Pinchera A. Detection and characterization of autoantibodies blocking the TSH-dependent cAMP production using FRTL-5 cells. J Endocrinol Invest 1987; 10: 383-388

[34] Vitti P, Chiovato L, Fiore E, Mammoli C, Rocchi R, Pinchera A. Use of cells expressing the human thyrotropin (TSH) receptor for the measurement of thyroid stimulating and TSH-blocking antibodies. Acta Med Austriaca 1996; 23: 52-56

[35] Brown RS, Bellisario RL, Botero D, Fournier L, Abrams CA, Cowger ML, David R, Fort P, Richman RA. Incidence of transient congenital hypothyroidism due to maternal thyrotropin receptor-blocking antibodies in over one million babies. J Clin Endocrinol Metab 1996; 81: 1147-1151

[36] Evans C, Jordan N], Owens G, Bradley D, Ludgate M, John R. Potent thyrotrophin receptor-blocking antibodies: a cause of transient congenital hypothyroidism and delayed thyroid development. Eur J Endocrinol 2004; 150: 265-268 
[37] Brown RS, Keating P, Mitchell E. Maternal thyroid-blocking immunoglobulins in congenital hypothyroidism. J Clin Endocrinol Metab 1990; 70: $1341-1346$

[38] Kiefer FW, Klebermass-Schrehof K, Steiner M, Worda C, Kasprian G, Diana T, Kahaly G], Gessl A. Fetal/Neonatal Thyrotoxicosis in a newborn from a hypothyroid woman with hashimoto thyroiditis. J Clin Endocrinol Metab 2017; 102: 6-9

[39] Sanders J, Evans M, Premawardhana LD, Depraetere H, Jeffreys J, Richards T, Furmaniak J, Rees Smith B. Human monoclonal thyroid stimulating autoantibody. Lancet 2003; 362: 126-128

[40] Evans M, Sanders J, Tagami T, Sanders P, Young S, Roberts E, Wilmot ], Hu X, Kabelis K, Clark J, Holl S, Richards T, Collyer A, Furmaniak J, Smith BR. Monoclonal autoantibodies to the TSH receptor, one with stimulating activity and one with blocking activity, obtained from the same blood sample. Clin Endocrinol (Oxf) 2010; 73: 404-412

[41] Giordano C, Stassi G, De Maria R, Todaro M, Richiusa P, Papoff G, Ruberti G, Bagnasco M, Testi R, Galluzzo A. Potential involvement of Fas and its ligand in the pathogenesis of Hashimoto's thyroiditis. Science 1997; 275: 960-963

[42] Stassi G, Di Liberto D, Todaro M, Zeuner A, Ricci-Vitiani L, Stoppacciaro A, Ruco L, Farina F, Zummo G, De Maria R. Control of target cell survival in thyroid autoimmunity by $\mathrm{T}$ helper cytokines via regulation of apoptotic proteins. Nat Immunol 2000; 1: 483-488

[43] Marinkovic T, Garin A, Yokota Y, Fu YX, Ruddle NH, Furtado GC, Lira SA. Interaction of mature CD3 $+C D 4+T$ cells with dendritic cells triggers the development of tertiary lymphoid structures in the thyroid. J Clin Invest 2006; 116: 2622-2632

[44] Chiovato L, Bassi P, Santini F, Mammoli C, Lapi P, Carayon P, Pinchera A. Antibodies producing complement-mediated thyroid cytotoxicity in patients with atrophic or goitrous autoimmune thyroiditis. J Clin Endocrinol Metab 1993; 77: 1700-1705

[45] Liblau RS, Singer SM, McDevitt HO. Th1 and Th2 CD4 + T cells in the pathogenesis of organ-specific autoimmune diseases. Immunol Today 1995; 16: 34-38

[46] Grubeck-Loebenstein B, Buchan G, Chantry D, Kassal H, Londei M, Pirich K, Barrett K, Turner M, WaldhausI W, Feldmann M. Analysis of intrathyroidal cytokine production in thyroid autoimmune disease: thyroid follicular cells produce interleukin-1 alpha and interleukin-6. Clin Exp Immunol 1989; 77: 324-330

[47] Fisfalen ME, Palmer EM, Van Seventer GA, Soltani K, Sawai Y, Kaplan E, Hidaka Y, Ober C, DeGroot LI. Thyrotropin-receptor and thyroid peroxidase-specific $\mathrm{T}$ cell clones and their cytokine profile in autoimmune thyroid disease. J Clin Endocrinol Metab 1997; 82: 3655-3663

[48] Mackenzie WA, Davies TF. An intrathyroidal T-cell clone specifically cytotoxic for human thyroid cells. Immunology 1987; 61: 101-103

[49] Chiovato L, Vitti P, Santini F, Lopez G, Mammoli C, Bassi P, Giusti L, Tonacchera M, Fenzi G, Pinchera A. Incidence of antibodies blocking thyrotropin effect in vitro in patients with euthyroid or hypothyroid autoimmune thyroiditis. J Clin Endocrinol Metab 1990; 71: 40-45

[50] Furmaniak ], Sanders ], Rees Smith B. Blocking type TSH receptor antibodies. Auto Immun Highlights 2012; 4: 11-26

[51] Endo K, Kasagi K, Konishi J, Ikekubo K, Okuno T, Takeda Y, Mori T, Torizuka K. Detection and properties of TSH-binding inhibitor immunoglobulins in patients with Graves' disease and Hashimoto's thyroiditis. J Clin Endocrinol Metab 1978; 46: 734-739

[52] Matsuura N, Yamada Y, Nohara Y, Konishi J, Kasagi K, Endo K, Kojima H, Wataya K. Familial neonatal transient hypothyroidism due to maternal TSH-binding inhibitor immunoglobulins. N Engl J Med 1980; 303: 738-741

[53] Arikawa K, Ichikawa Y, Yoshida T, Shinozawa T, Homma M, Momotani N, Ito K. Blocking type antithyrotropin receptor antibody in patients with nongoitrous hypothyroidism: its incidence and characteristics of action. J Clin Endocrinol Metab 1985; 60: 953-959
[54] Ambesi-Impiombato FS. Living, fast-growing thyroid cell strain, FRTL-5. In: Google Patents; US4608341A US Grant; 1986

[55] Massart C, Gibassier J, Verite F, Fergelot P, Maugendre D. Use of Chinese hamster ovary cell lines transfected with cloned human thyrotropin receptor for the measurement of thyroid-stimulating antibodies: advantages and difficulties. Clin Chim Acta 2000; 291: 67-81

[56] Grasso YZ, Kim MR, Faiman C, Kohn LD, Tahara K, Gupta MK. Epitope heterogeneity of thyrotropin receptor-blocking antibodies in Graves' patients as detected with wild-type versus chimeric thyrotropin receptors. Thyroid 1999; 9: 531-537

[57] Tahara K, Ishikawa N, Yamamoto K, Hirai A, Ito K, Tamura Y, Yoshida S, Saito Y, Kohn LD. Epitopes for thyroid stimulating and blocking autoantibodies on the extracellular domain of the human thyrotropin receptor. Thyroid 1997; 7: 867-877

[58] Minich WB, Lenzner C, Bergmann A, Morgenthaler NG. A coated tube assay for the detection of blocking thyrotropin receptor autoantibodies. J Clin Endocrinol Metab 2004; 89: 352-356

[59] Kamijo K, Nagata A, Sato Y. Clinical significance of a sensitive assay for thyroid-stimulating antibodies in Graves' disease using polyethylene glycol at high concentrations and porcine thyroid cells. Endocr J 1999; 46: 397-403

[60] Yamasa https://www.yamasa.com/shindan/english/shindan/tsab.htm

[61] FIRS Laboratories. RSR, Ltd. Assay Service. Thyroid blocking (TSBAb) bioassay. Available at www.rsrltd.com/assay_service.html

[62] Smith BR, Bolton J, Young S, Collyer A, Weeden A, Bradbury ], Weightman D, Perros P, Sanders J, Furmaniak J. A new assay for thyrotropin receptor autoantibodies. Thyroid 2004; 14: 830-835

[63] Araki N, lida M, Amino N, Morita S, Ide A, Nishihara E, Ito M, Saito ], Nishikawa T, Katsuragi K, Miyauchi A. Rapid bioassay for detection of thyroid-stimulating antibodies using cyclic adenosine monophosphate-gated calcium channel and aequorin. Eur Thyroid J 2015; 4: $14-19$

[64] Takasu N, Yamada T, Katakura M, Yamauchi K, Shimizu Y, Ishizuki Y. Evidence for thyrotropin (TSH)-blocking activity in goitrous Hashimoto's thyroiditis with assays measuring inhibition of TSH receptor binding and TSH-stimulated thyroid adenosine 3',5'-monophosphate responses/cell growth by immunoglobulins. J Clin Endocrinol Metab 1987; 64: 239-245

[65] Kawahara K, Tsukimoto I, Yokoya S. Atrophic autoimmune thyroiditis with positive thyroid stimulation blocking antibody in a prepubertal boy. Clin Pediatr Endocrinol 2000; 9: 105-111

[66] Cho BY, Shong YK, Lee HK, Koh CS, Min HK. Inhibition of thyrotropin-stimulated adenylate cyclase activation and growth of rat thyroid cells, FRTL-5, by immunoglobulin G from patients with primary myxedema: Comparison with activities of thyrotropin-binding inhibitor immunoglobulins. Acta Endocrinol (Copenh) 1989; 120: 99-106

[67] Cho BY, Shong YK, Lee HK, Koh CS, Min HK, Sohn I. Role of blocking TSH receptor antibodies on the development of hypothyroidism and thyroid atrophy in primary myxedema. Korean J Intern Med 1989; 4: 108-117

[68] Yoshikawa N, Nishikawa M, Horimoto M, Uno C, Taniguchi N, Inada M. Activity of thyroid stimulating antibody and thyroid stimulation blocking antibody determined by radioiodine uptake into FRTL- 5 cells. Endocrinol Jpn 1989; 36: 55-63

[69] Chiovato L, Vitti P, Bendinelli G, Santini F, Fiore E, Tonacchera M, Mammoli C, Capaccioli A, Venturi S, Pretell E. Humoral thyroid autoimmunity is not involved in the pathogenesis of myxedematous endemic cretinism. J Clin Endocrinol Metab 1995; 80: 1509-1514

[70] Kraiem Z, Cho BY, Sadeh O, Shong MH, Pickerill P, Weetman AP. The $\mathrm{IgG}$ subclass distribution of TSH receptor blocking antibodies in primary hypothyroidism. Clin Endocrinol (Oxf) 1992; 37: 135-140 
[71] Kraiem Z, Baron E, Kahana L, Sadeh O, Sheinfeld M. Changes in stimulating and blocking TSH receptor antibodies in a patient undergoing three cycles of transition from hypo to hyper-thyroidism and back to hypothyroidism. Clin Endocrinol (Oxf) 1992; 36: 211-214

[72] Kung AW, Jones BM. A change from stimulatory to blocking antibody activity in Graves' disease during pregnancy. J Clin Endocrinol Metab 1998; 83: 514-518

[73] Wallaschofski H, Paschke R. Detection of thyroid stimulating (TSAB)and thyrotropin stimulation blocking (TSBAB) antibodies with $\mathrm{CHO}$ cell lines expressing different TSH-receptor numbers. Clin Endocrinol (Oxf) 1999; 50: 365-372

[74] Wallaschofski H, Kaczmarek M, Miehle K, Hentschel B, Paschke R. Differences between thyrotropin receptor antibody bioactivity and inhibition of 125I-bovine thyrotropin binding. Thyroid 2000; 10: 897-907

[75] Tada H, Izumi Y, Watanabe Y, Takano T, Fukata S, Kuma K, Hidaka Y, Amino N. Blocking type anti-tSH receptor antibodies detected by radioreceptor assay in Graves' disease. Endocr J 2001; 48: 703-710

[76] Diana T, Krause J, Olivo PD, Konig J, Kanitz M, Decallonne B, Kahaly G]. Prevalence and clinical relevance of thyroid stimulating hormone receptor-blocking antibodies in autoimmune thyroid disease. Clin Exp Immunol 2017; 189: 304-309

[77] Tada H, Mizuta I, Takano T, Tatsumi KI, Izumi Y, Hidaka Y, Amino N. Blocking-type anti-TSH receptor antibodies and relation to responsiveness to antithyroid drug therapy and remission in Graves' disease. Clin Endocrinol (Oxf) 2003; 58: 403-408

[78] Iseki M, Shimizu M, Oikawa T, Hojo H, Arikawa K, Ichikawa Y, Momotani N, Ito K. Sequential serum measurements of thyrotropin binding inhibitor immunoglobulin $\mathrm{G}$ in transient familial neonatal hypothyroidism. J Clin Endocrinol Metab 1983; 57: 384-387

[79] Michelangeli VP, Poon C, Topliss DJ, Colman PG. Specific effects of radioiodine treatment on TSAb and TBAb levels in patients with Graves' disease. Thyroid 1995; 5: 171-176

[80] Valente WA, Vitti P, Yavin Z, Yavin E, Rotella CM, Grollman EF, Toccafondi RS, Kohn LD. Monoclonal antibodies to the thyrotropin receptor: Stimulating and blocking antibodies derived from the lymphocytes of patients with Graves disease. Proc Natl Acad Sci U S A 1982; 79: 6680-6684

[81] Sanders ], Evans M, Betterle C, Sanders P, Bhardwaja A, Young S, Roberts E, Wilmot J, Richards T, Kiddie A, Small K, Platt H, Summerhayes S, Harris R, Reeve M, Coco G, Zanchetta R, Chen S, Furmaniak J, Smith BR. A human monoclonal autoantibody to the thyrotropin receptor with thyroid-stimulating blocking activity. Thyroid 2008; 18: 735-746
[82] Furmaniak J, Sanders J, Rees Smith B. Blocking type TSH receptor antibodies. Auto Immun Highlights 2012; 4: 11-26

[83] Rees Smith B, Sanders ], Evans M, Tagami T, Furmaniak J. TSH receptor - Autoantibody interactions. Horm Metab Res 2009; 41: 448-455

[84] Furmaniak J. In vivo effects of a human thyroid-stimulating monoclonal autoantibody (M22) and a human thyroid-blocking autoantibody (K1-70). Auto Immun Highlights 2012; 3: 19-25

[85] Kahaly G], Kanitz M, Kolbe E, Matheis N, Diana T. Thyroid stimulating autoantibodies are clinically useful and predictive in graves' disease A prospective trial. Eur Thyroid J 2014; 3: (Suppl 1): 91

[86] Cove DH, Johnston P. Fetal hyperthyroidism: experience of treatment in four siblings. Lancet 1985; 1: 430-432

[87] Kung AW, Yeung SS. Prevention of bone loss induced by thyroxine suppressive therapy in postmenopausal women: The effect of calcium and calcitonin. J Clin Endocrinol Metab 1996; 81: 1232-1236

[88] McLachlan SM, Rapoport B. Thyrotropin-blocking autoantibodies and thyroid-stimulating autoantibodies: Potential mechanisms involved in the pendulum swinging from hypothyroidism to hyperthyroidism or vice versa. Thyroid 2013; 23: 14-24

[89] Bossowski A, Moniuszko M, Idzkowska E, Grubczak K, Singh P, Bossowska A, Diana T, Kahaly G]. Decreased proportions of CD4 + $\mathrm{IL} 17+/ \mathrm{CD} 4+\mathrm{CD} 25+\mathrm{CD} 127-$ and CD4 + IL17 + /CD4 + CD25 + CD127 - FoxP3 + T cells in children with autoimmune thyroid diseases. Autoimmunity 2016; 49: 320-328

[90] McKenzie JM, Zakarija M. Fetal and neonatal hyperthyroidism and hypothyroidism due to maternal TSH receptor antibodies. Thyroid 1992; 2: 155-159

[91] Abeillon-du Payrat J, Chikh K, Bossard N, Bretones P, Gaucherand P, Claris O, Charrie A, Raverot V, Orgiazzi J, Borson-Chazot F, Bournaud C. Predictive value of maternal second-generation thyroid-binding inhibitory immunoglobulin assay for neonatal autoimmune hyperthyroidism. Eur J Endocrinol 2014; 171: 451-460

[92] Feingold SB, Smith J, Houtz J, Popovsky E, Brown RS. Prevalence and functional significance of thyrotropin receptor blocking antibodies in children and adolescents with chronic lymphocytic thyroiditis. J Clin Endocrinol Metab 2009; 94: 4742-4748 